\title{
Colocasia esculenta (L.) Schott (Araceae), an expanding invasive species of aquatic ecosystems in the Iberian Peninsula: new records and risk assessment
}

\author{
Elías D. Dana ${ }^{1, *}$, Juan García-de-Lomas ${ }^{2}$, Filip Verloove ${ }^{3, *}$, David García-Ocaña ${ }^{4}$, Vanesa \\ Gámez $^{5}$, Juan Alcaraz ${ }^{6}$ and José Miguel Ortiz ${ }^{7}$ \\ ${ }^{1}$ Grupo de Investigación, Transferencia I+D en Recursos Naturales, Universidad de Almería (Almería, Spain). \\ ${ }^{2}$ Grupo de Investigación Estructura y Dinámica de Ecosistemas Acuáticos, Universidad de Cádiz (Cádiz, Spain). \\ ${ }^{3}$ Botanic Garden of Meise, Nieuwelaan 38, B-1860 Meise (Belgium). \\ ${ }^{4}$ Calle Delfín, $41^{\circ}$ B izquierda.18015, Granada (Spain). \\ ${ }^{5}$ Calle El Valle, 1. 18813 Cuevas del Campo, Granada (Spain). \\ ${ }^{6}$ Casa Forestal del monte dunas de Tarifa, CP. 11380, Tarifa (Spain). \\ ${ }^{7}$ Oficina Administrativa Agentes de Medio Ambiente. Plaza de Andalucía 22, 11350-Castellar de la Frontera, \\ Cádiz (Spain).
}

*Corresponding author: eliasdana.ecology@gmail.com and filip.verloove@plantentuinmeise.be

Received: $16 / 12 / 15 \quad$ Accepted: 15/12/16

\begin{abstract}
Colocasia esculenta (L.) Schott (Araceae), an expanding invasive species of aquatic ecosystems in the Iberian Peninsula: new records and risk assessment

Colocasia esculenta (L.) Schott, Araceae, is becoming an invasive plant in Spain (Iberian Peninsula). Four newly invaded localities are presented in this study, and its population status, habitat and climatic features in Spain are presented. The species has colonised some localities in south Portugal. To characterise the species' climatic tolerance, its world distribution was reviewed, and the climate types of other invaded areas worldwide were identified. Global data show that the species has the potential to colonise aquatic ecosystems under a wide variety of climate types. Finally, based on two different procedures, risk assessments were conducted for the Iberian Peninsula and for continental Europe. Both suggested a high ecological risk associated with this species. Caution is called for in terms of its use outside of its native distribution range. It is proposed that this species should be considered as invasive and risky to European and Iberian water bodies and should be legally banned in Europe.
\end{abstract}

Key words: Plant invasion, climate, risk assessment, Köppen-Geiger, Spain, Portugal, European Union.

\section{RESUMEN}

Colocasia esculenta (L.) Schott (Araceae), una invasora en expansión por los ecosistemas acuáticos ibéricos: nuevos registros y análisis de riesgos

Colocasia esculenta (L.) Schott, Araceae, se está convirtiendo en una especie invasora en España (península ibérica). En este estudio se da cuenta de cuatro nuevas localidades invadidas, para las que se describen el estado de las poblaciones, las características del hábitat invadido y los rasgos climáticos de las localidades invadidas en España. La especie ha colonizado algunas localidades del Sur de Portugal. Se revisa su distribución mundial y los parámetros climáticos de las áreas invadidas a fin de caracterizar su tolerancia climática. El conjunto de datos muestra que la especie tiene amplia capacidad para colonizar ecosistemas acuáticos de agua bajo un amplio rango de condiciones climáticas. Finalmente, empleando como contraste dos métodos diferentes, se realiza un análisis del riesgo de invasión a dos escalas, Península Ibérica y Europa. En ambos casos los resultados alertan del alto riesgo ecológico asociado a la especie. Se hace una llamada a la precaución sobre su uso fuera de su rango nativo, y se propone que la especie debería ser considerada como invasora y de riesgo para los humedales europeos e ibéricos, y por ello, legalmente prohibida en Europa.

Palabras clave: Invasión por plantas, clima, análisis de riesgos, Köppen-Geiger, España, Portugal, Unión Europea. 


\section{INTRODUCTION}

Colocasia esculenta (L.) Schott, Araceae (taro, elephant ear or cocoyam), is an emergent, perennial, semi-aquatic herbaceous Asian plant species (Plucknett, 1976). Within its native range, $C$. esculenta grows in tropical areas with high rainfall (1800-2500 mm/year) and temperatures in the range of $25-35^{\circ} \mathrm{C}$. It occurs mainly in wetlands with low salinity levels $(<5 \mathrm{mM} \mathrm{NaCl})$, although it can also be found in dry lowland environments (Fujimoto, 2009). Taro was one of the earliest crop plants in the Solomon Islands and New Guinea, where it has been grown for more than 10,000 years (Loy et al., 1992). Currently, C. esculenta is commonly cultivated in many warm and tropical areas, and it is the fifth most consumed root vegetable worldwide (Mace \& Godwin, 2002). This species has also been traditionally cultivated outside the tropics, including in some Mediterranean areas such as Portugal, the Canary Islands and Madeira. Some authors (García-Sánchez et al., 2008; García-Sánchez, 2013) consider that the species was likely grown in the Iberian Peninsula in al-Andalus both as a crop, frequently associated with banana (Musa sp.) and sugarcane (Saccharum officinarum) farming, and as an ornamental plant in orchards. Indeed, ornamental use is also frequent in warm areas of the world (Wirth et al., 2004).

$C$. esculenta has shown invasive behaviour in several warm and temperate areas of the world. Extensive stands of elephant ear alter the vegetation composition, structure and dynamics of riparian plant communities. Many cultivars are well adapted to saline conditions, low water availability and/or seasonally flooded soils and are also widely cultivated throughout tropical and subtropical regions (Onwueme, 1999). By virtue of its corms, or vegetative fragments, it may become invasive along irrigation channels and surrounding lands, riversides and lakes, where it can modify the vegetation composition and structure as well as the dynamics of riparian plant communities (Cufodontis, 1953-1972; Kunkel, 1975; Wester, 1992; Visser et al., 1999; FLEPPC, 2000; Tye, 2001; Brown \& Brooks, 2003; GarcíaCamacho \& Quintanar, 2003; Henderson, 2007;
Atkins \& Williamson, 2008; Silva et al., 2008; Ferrer-Gallego et al., 2015). C. esculenta is also an allelopathic species (Pardales et al., 1992). These undesired ecological consequences have led to the implementation of management actions to control invasive populations (Brown \& Brooks, 2003; Atkins \& Williamson, 2008). However, little attention has been paid to this species as an invasive plant in the Iberian Peninsula. García-de-Lomas et al. (2012) reported the details of the reproduction, spreading patterns and dynamics of an invasion record in southern Spain, whose origin could be associated with private ornamental use of the species. In this area, the plant grew as dense stands along rivulets and showed evidence of rapid downstream spread by means of satellite (coloniser fragment) individuals. These authors also recommended further studies on its potential invasion in freshwater wetlands at broader geographical scales. More recently, Ferrer-Gallego et al. (2015) reported two invaded wetlands in eastern Spain, where control actions are being implemented.

In the present work, we provide four novel field records for taro, review the climatic characteristics of other invaded locations worldwide and conduct risk analyses for this species in continental Europe.

\section{MATERIALS AND METHODS}

Our findings of new naturalised populations of C. esculenta located in the south of Spain are incidental. These findings led us to review the species' status in the wild in the Iberian Peninsula. For each new population found, the following data are provided: UTM projected coordinates (Datum ETRS89/TM30), date of observation, habitat, accompanying species, size of the area invaded and climatic parameters (average annual rainfall; average, minimum and maximum mean temperature and minimum temperature of the coolest month). The climatic data and climate type of each locality were retrieved from climatedata.org, an online database built from a model containing more than 220 million data points collected between 1982 and 2012 and a resolution of 
30 arcseconds (0.0083 decimal degrees), or approximately one square $\mathrm{km}$. Xenotype was assigned following Kornaś (1990) and Sanz-Elorza et al. (2004) according to the habitat features and population state.

Records showing the status of $C$. esculenta as naturalised or invasive were reviewed in published papers and main flora databases such as GBIF (http://www.gbif.org), CABI (http://www. cabi.org/isc), and Discover Life (http://www.dis coverlife.org). Records that did not unequivocally refer to naturalised populations were discarded.

To evaluate the climatic amplitude of the species, we followed two independent procedures. The first procedure used 'Climatch' online software (available at http://data.daff.gov.au:80 80/Climatch/climatch.jsp). The underlying algorithm produces a classification of localities based on the similarity level shown by climatic features between the source localities (i.e., the climatic station nearest to the invaded locality in the Iberian Peninsula) and the target localities (in this work, the rest of the localities with climatic stations). The resolution of this model is lower than that required by the risk analysis questionnaire developed by Garcia-de-Lomas et al. (2014) -1 $\mathrm{km}^{2}$ - since it classifies similarities between points (locations of climatic stations). 'Closest Euclidean match' was chosen as the algorithm to calculate the 'climate distance' between the input sites and each target site across the climate variables used in the analysis (Elmore \& Richman 2001; Crombie et al., 2008). All climatic variables recorded were used in the analysis to gather the maximum environmental variability. Fourteen stations located in the surroundings of clearly naturalised populations of $C$. esculenta were used as the source region. Seventy-six stations covering a territory extent of ca. $472.510 \mathrm{~km}^{2}$ were employed as the target region for comparison. The results obtained were contrasted with those retrieved using the closest standard score as a distance measure. Since they were almost identical, only the results obtained with the Euclidean metric are presented in this work. This procedure was applied only to predictions at the scale of the Iberian Peninsula in order to reduce potential interferences caused by heterogeneity among the floristic records published worldwide in a so widely spread species and to reduce the influence of errors that could be introduced by the analyser's selection criteria of so many climatic stations as source data.

The second procedure for climate analysis was based on inspecting those regions depicted by their climatic similarity in the World Map of the Köppen-Geiger climate classification (Kottek et al., 2006). In this system, the first letter describes the main climate classes, namely tropical (A), arid (B), warm-temperate (C), cold-temperate (D) and cold climates (E). The second letter accounts for precipitation regimes: hot (h) and cool (k). The third letter refers to the temperature classes: hot summer (a), warm summer (b), dry, short summer (c) and very cold winter (d). This second analysis was applied to European countries. First, we identified the climate types of the regions in which $C$. esculenta has become invasive in the world. The European areas where those climate-types are represented were depicted using the general world map prepared by Wilkerson \& Wilkerson (2010). The final map, freely available to users, has a spatial resolution of 0.5 degree, which seems more than sufficient to conduct a visual inspection of the distribution ranges of the climatic conditions required by the species across large territories.

Finally, with all the information gathered, a risk analysis assessment was conducted following two different procedures (Gordon et al., 2010; García-de-Lomas et al., 2014) to evaluate the invasion risk in the Iberian Peninsula and in the continental part of the European Union as a whole. The use of these two different approaches helps to inspect the robustness of the results obtained. The first method is based on the Australian Weed Risk Assessment, WRA (Pheloung, 1995). The WRA scheme follows a quantitative scoring method, which adds the scores obtained from 49 questions on biogeography, biology/ecology, and traits contributing to invasiveness. Depending on the answer, each question is awarded between 3 and 5 points (mostly 1 to 1 ), and the final WRA score is the sum of the points for all answered questions. 
This final score, ranging potentially from -14 (benign taxa) to 29 (maximum risk), leads to one of three outcomes: the species is accepted for introduction ( $<1$ total points), rejected ( $>6$ points), or recommended for further evaluation of invasive potential (1-6 points). The type of response for each criterion is simple (yes, no; low-intermediate-high) but rather prone to subjectivity. As a consequence, we followed the particular instructions to fill the questionnaire developed by Gordon et al. (2010).

The second method, proposed by García-deLomas et al. (2014), follows a semi-quantitative scoring system. A total of 19 criteria were considered, including biological features and potential impacts as well as two specific questions related to the potential impacts on economy and human health. The questions were grouped into three categories (critical, key and secondary). Thus, if any of the critical questions has been answered with the option "a", the output is "high risk". If more than three key questions have been answered with the option "a", the output is "high risk". Each question receives generally from 0 to 5 points. If all questions are answered, the final sum varies between -14 and 63 . To facilitate easier interpretation, this output value is then transformed onto a 0-100 scale, so that the final output is "low risk" (total sum $<54$ points) or high risk (total sum $\geq 54$ points). Therefore,

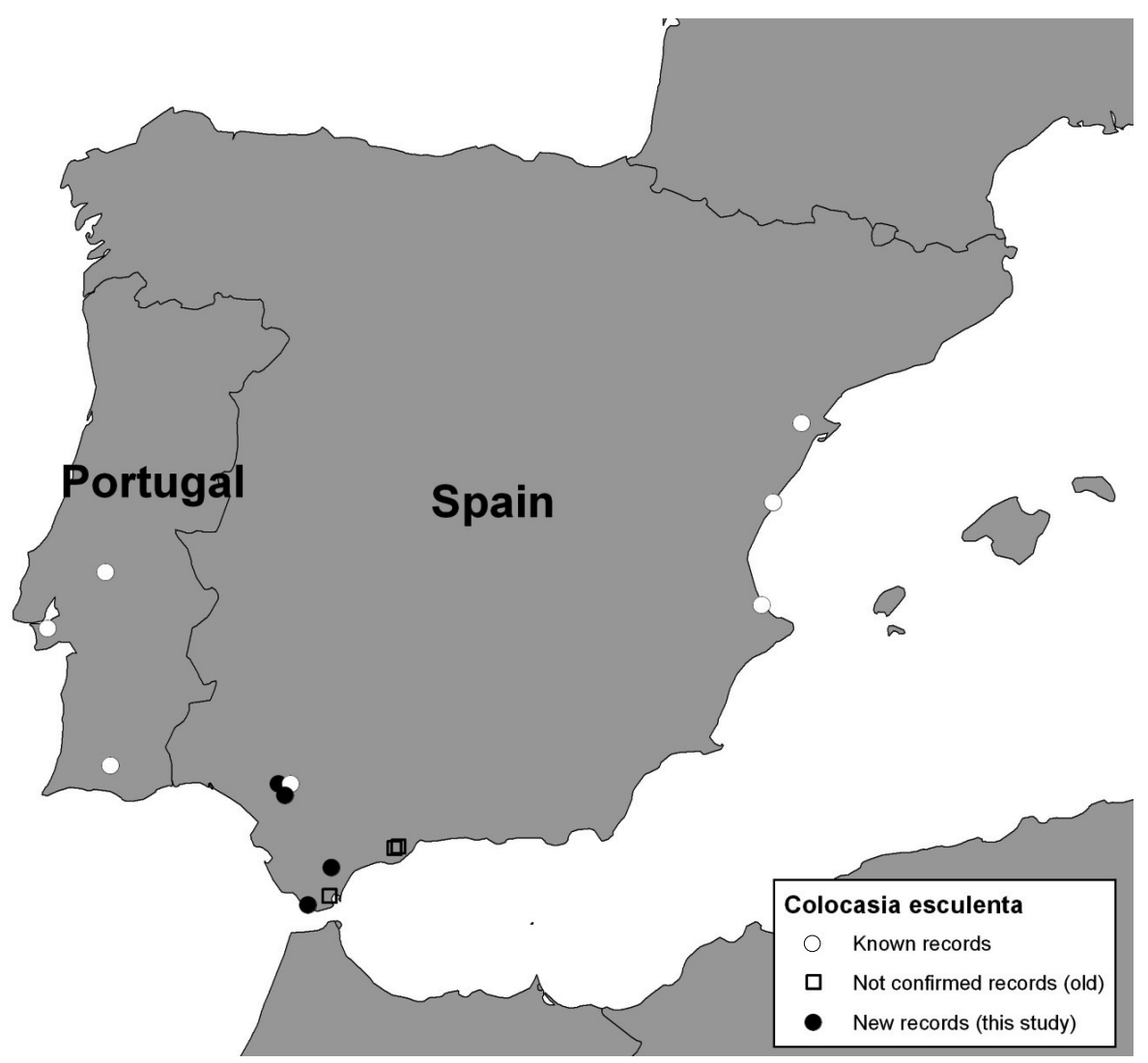

Figure 1. Published records of Colocasia esculenta (L.) Schott in the Iberian Peninsula. Empty squares show records indicated in the ancient literature, which could not be confirmed in this study, likely due to the heavy environmental modifications caused by humans in those areas. Records from Portugal must be considered at present as ephemerophytes escaped from cultivated lands. The remaining dots correspond to naturalised populations. Registros publicados de Colocasia esculenta (L.) Schott en la península ibérica. Los cuadrados vacíos muestran registros indicados por literatura antigua, que no pudieron ser confirmados en este estudio, probablemente por las profundas modificaciones ambientales provocadas por el ser humano en esas áreas. Los registros de Portugal deben ser considerados, por ahora, como efemerófitos escapados de cultivos adyacentes. El resto de registros corresponde a las poblaciones naturalizadas. 
only two outputs are possible ("high risk", "low risk"). This method reduces the time of evaluation since the evaluator rarely needs to answer all the questions. The possibility to answer "unknown" is always included as a measure of uncertainty. As a precautionary approach, if all questions were answered as "unknown", the output is "high risk" (it is assumed that if there is no available information on one species, the species should not be introduced within a new territory). This protocol also requires the inclusion of the source of information used to ensure objectivity and transparency. A synthesis of the relevant information for risk analyses is provided in Supplementary Information (see Tables S1, S2, available at www.limnetica.com).

Vouchers for some of the new records in Spain were deposited in the MGC herbarium (the herbarium of the University of Malaga).

\section{RESULTS AND DISCUSSION}

\section{Newly invaded localities}

Four new records of Colocasia esculenta are reported here. The maximum distance between the newly detected populations is $135 \mathrm{~km}$. The new records included a variety of habitats colonised, including stream banks and artificial wetlands.

- Cádiz, Punta Paloma (Parque Natural del Estrecho, Tarifa), 48 m.a.s.l. Coordinates: 254401/3995053. Date: 19/06/2015. Length invaded: $25 \mathrm{~m}$. Mean cover density $=100 \%$. Habitat and main species: temporal stream under pinewood (Pinus pinea L., Rubus ulmifolius Schott, Smilax aspera L.). Xenotype: naturalised as hemiagriophyte. Voucher: MGC 81003, Legit.: Juan Alcaraz. Det.: E.D. Dana.

- Cádiz, Jimena de la Frontera, in temporal stream joining Hozgarganta River, on the path named Pasada de Alcalá, near council's Ethnobotanical Garden (Parque Natural Los Alcornocales), 92 m.a.s.l. Coordinates: 279613/4035216. Date: 15/10/2013. Length invaded: $150 \mathrm{~m}$. Mean cover density $=100 \%$.
Habitat and main species: temporal Mediterranean stream connected to Hozgarganta River in open ground with Rubus ulmifolius Schott. Xenotype: naturalised as hemiagriophyte. Voucher: MGC 80806 and 81213, Legit.: D. García Ocaña, V. Gámez \& J.M. Ortiz. Det.: E.D. Dana.

- Sevilla, La Puebla del Rio (Cañada de los Pájaros, Reserva Natural Concertada), 10 m.a.s.l. Coordinates: 222509/4126114. Date: 18/10/2014. Length invaded: $30 \mathrm{~m}$. Mean cover $=50 \%$. Habitat and main species: artificially swamped soils with other invasive species, Eichhornia crassipes (Mart.) Solms 1883, Cyperus sp. Xenotype: epoecophyte. Field observation on private land, no voucher available (obs. J. García-de-Lomas).

- Sevilla, Utrera (Paraje Natural Brazo del Este), 20 m.a.s.1. Coordinates: 229542/4113475. Date: 23/11/2015. Length invaded: $3 \mathrm{~m}$. Mean cover $=100 \%$. Habitat and main species: marshland, Phragmites australis (Cav.) Trin. ex Steud. Xenotype: holoagriophyte. Field observation, no voucher available (obs. J.A. Barragán and E.D. Dana).

In Spain, there are a few additional reports of naturalised patches of $C$. esculenta in the $\mathrm{XIX}^{\text {th }}$ century in Málaga and Cádiz provinces (Fig. 1), but, as geographic coordinates are too vague, its persistence cannot currently be confirmed. Boissier (1839) found it near Churriana (30SUF65) and in Alhaurinejo (30SUF55) and Alhaurín (30SUF45) ("In humidiusculis regionis calida e ferè spontanea"). Additionally, PérezLara (1886) recorded the species in Algeciras (Barranco del Quejigo, 30STF80) and in an unspecified location between Jimena de la Frontera and Alcalá (30STF83). Subsequent references have never confirmed the species in these or other localities nearby (e.g., Casimiro-Soriguer $\&$ Pérez-Latorre, 2008). This may be due to the increased urbanisation in Málaga province where the species was initially located (Moreira, 2011), whereas the localities reported in Cádiz province are too imprecise to be located. Other sources have reported naturalised populations of $C$. es- 
culenta in seminatural wetlands in Valencia and Castellón (Ferrer-Gallego et al., 2015) and Tarragona (Balada, 1993; Royo, 2006; Curcó, 2007).

It must be highlighted that the four new Spanish localities presented in this work are located within protected areas. Of great importance is the new patch found in Sevilla (Brazo del Este, Natural Area). It appears to be isolated and several kilometres away from the nearest known population (García-de-Lomas et al., 2012). In less than four years, it has colonised a new distant point, which seems to confirm the prediction by Garcíade-Lomas et al. (2012) that those water bodies located downstream of an invaded course are under high risk of being invaded over short periods of time.

The status of this species in mainland Portugal is unclear. 'Taro' has not been recorded as an established invasive species in continental Portugal by the most recent and comprehensive studies (Sequeira et al., 2011; Almeida \& Freitas, 2012). However, it shows clear invasive behaviour and

Table 1. Main climatic features of localities in which Colocasia esculenta (L.) Schott has been found in the Iberian Peninsula. Climate type according to Köppen-Geiger's system, updated by Kottek et al. (2006). Records from Portuguese localities must be considered at present as ephemerophytes escaped from cultivated lands. Principales parámetros climáticos de las localidades de las que se conoce la presencia de Colocasia esculenta (L.) Schott. La designación del tipo climático sigue a Köppen-Geiger's system, actualizado por Kottek et al. (2006). * Los registros de las localidades portuguesas deben considerarse, por ahora, como escapes procedentes de cultivos próximos.

\begin{tabular}{|c|c|c|c|c|c|c|c|c|c|c|c|c|}
\hline LOCATION & 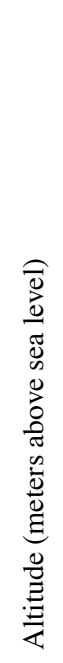 & 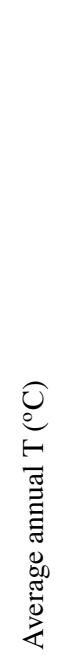 & 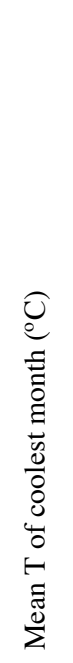 & 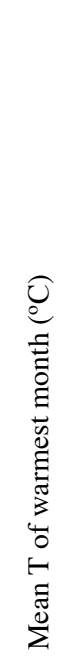 & 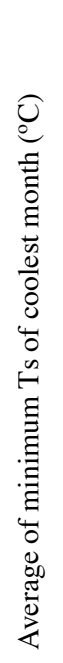 & 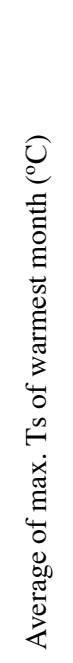 & 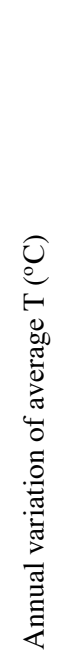 & 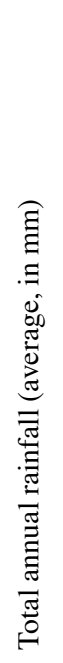 & 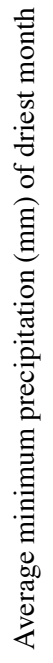 & 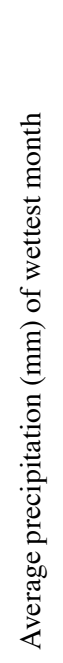 & 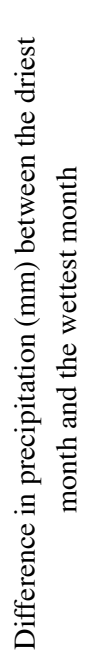 & 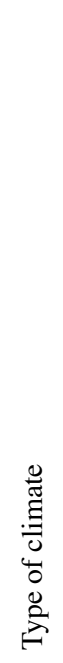 \\
\hline \multicolumn{13}{|c|}{ SPAIN } \\
\hline TARIFA & 52 & 17.2 & 11.8 & 23.4 & 7.9 & 27.7 & 11.6 & 834 & 0 & 140 & 146 & Csa \\
\hline JIMENA & 24 & 17.6 & 12.0 & 24.3 & 8.1 & 34.5 & 12.3 & 739 & 1 & 130 & 129 & Csa \\
\hline DOS HERMANAS & 47 & 18.1 & 10.3 & 27.1 & 5.8 & 35 & 16.8 & 591 & 1 & 89 & 88 & Csa \\
\hline LA PUEBLA DEL RÍO & 28 & 18.3 & 10.4 & 27.1 & 6.0 & 34.6 & 16.0 & 574 & 1 & 87 & 86 & Csa \\
\hline GANDÍA & 26 & 18.0 & 11.2 & 26.1 & 6.4 & 30.9 & 14.9 & 497 & 7 & 83 & 76 & BSk \\
\hline CASTELLÓN DE LA PLANA & 34 & 17.0 & 10.1 & 24.7 & 6.1 & 28.8 & 14.6 & 434 & 13 & 68 & 55 & BSk \\
\hline TARRAGONA & 53 & 17.0 & 9.5 & 25.0 & 5.4 & 29.9 & 15.5 & 536 & 13 & 82 & 69 & Csa \\
\hline \multicolumn{13}{|c|}{ PORTUGAL* } \\
\hline MONCHIQUE & 439 & 14.8 & 9.6 & 21.3 & 5.8 & 27.3 & 11.7 & 624 & 2 & 98 & 96 & $\mathrm{Csb}$ \\
\hline ORTIGA & 132 & 16.6 & 10.2 & 24.0 & 6.7 & 30.7 & 13.8 & 759 & 6 & 109 & 103 & Csa \\
\hline BARREIRO & 8 & 17.0 & 11.6 & 23.0 & 8.5 & 28.3 & 11.4 & 678 & 3 & 103 & 100 & Csa \\
\hline
\end{tabular}


associated impacts on the Portuguese islands of Madeira and Azores (Silva et al., 2008). On the other hand, several records exist for mainland Portugal in the databases. The most interesting information is presented in the GBIF database, which identifies three localities based on personal observations by André Carapeto in 2013 in Monchique (Faro) and Barreiro (Setúbal) (Sociedade Portuguesa de Botânica, 2016). However, the information provided by the original reference does not allow these populations to be considered established. At least the references for Monchique seem to be escapes from nearby cultivations (Paulo Alves, personal communication). The CABI database contains a reference (http: //www.cabi.org/isc/datasheet/17221), but this record in fact points to undefined general comments made by the EPPO database (2014) regarding its presence on Madeira and Azores. Therefore, this record is not useful for this work. Finally, another record is presented by the database Discover Life (http://www.discoverlife.org/mp/20q), which, in fact, points to a sequence deposit at GenBank. No information is provided about the origin of the sample, which led us to discard the reference. We are aware of escaped individuals in the Monchique area (P. Alves, personal communication). Therefore, in view of their potential interest, we would suggest specific future assessment of the populations observed in Portugal by the Sociedade Portuguesa de Botânica (2016).

Finally, it is important to note that since the streams of the Iberian Peninsula have not been extensively sampled in search of this species and that since all the records published here correspond to incidental findings, it seems reasonable to assume that the presence of $C$. esculenta as naturalised in the Iberian Peninsula could be, to some extent, underestimated.

\section{Habitat and climate features}

In Spain, C. esculenta invades small temporary streams, irrigation channels, inland wetlands and large rivers, such as the Ebro (Balada, 1993; Ferrer-Gallego et al., 2015). The southernmost populations of this species are established as hemiagriophytes and holoagriophytes in water- courses. In all cases, the origin of the naturalised populations seems to be associated with escapes from nearby gardens.

The current distribution of $C$. esculenta in Spain shows a wide range of environmental parameters such as the differences in precipitation values between the driest and the wettest month (55-146 mm, Table 1), average temperatures $\left(11.6-16.8^{\circ} \mathrm{C}\right)$, mean annual rainfall values $(434-834 \mathrm{~mm})$ and minimum temperatures of the coolest month $\left(5.4-8.1{ }^{\circ} \mathrm{C}\right)$. The reasons underlying the species' tolerance to this variation in climatic parameters may correspond to its growth form (as a geophyte, dormant organs are protected underground during the coldest months of the year) and habitat types colonised, since watercourses and wetlands may compensate for variations in rainfall among years and buffer temperature extremes at the micro-site level.

According to the climate classification of Köppen-Geiger (Kottek et al., 2006), the invaded areas in the Iberian Peninsula are associated with the climate subtypes ' $\mathrm{Csa}$ ' and 'Csb' (warm temperature, dry and hot -'Csa'- or dry and warm - 'Csb'- summer) in the central and south of the Iberian Peninsula and 'Bsk' (arid, dry summer, cold arid) in the east of Spain (Kottek et al., 2006). The 'Csa' type is present in the Mediterranean part of Europe and in southern Portugal, Turkey and eastern Mediterranean countries, as well as in the coastal territories of Morocco, Tunisia and Algeria, parts of Libya, and some areas of the Irano-Turanian regions, India, south and south-western Australia, and California. 'Csb' may be interpreted as a transition towards subtypes with more mild summers. The 'Bsk' climate type is mainly represented in more continental areas and appears in several countries of central Asia, south Australia, south Argentina, central and north Mexico and the central inner states of the USA.

Table 2 shows the climate type correspondence to invaded areas worldwide. It is obvious that the species may appear in the wild under a large number of climatic conditions: equatorial savannah with dry winter ('Aw'), the aforementioned warm temperate climate with dry summer (with hot or warm summer, 'Csa' and 'Csb', re- 


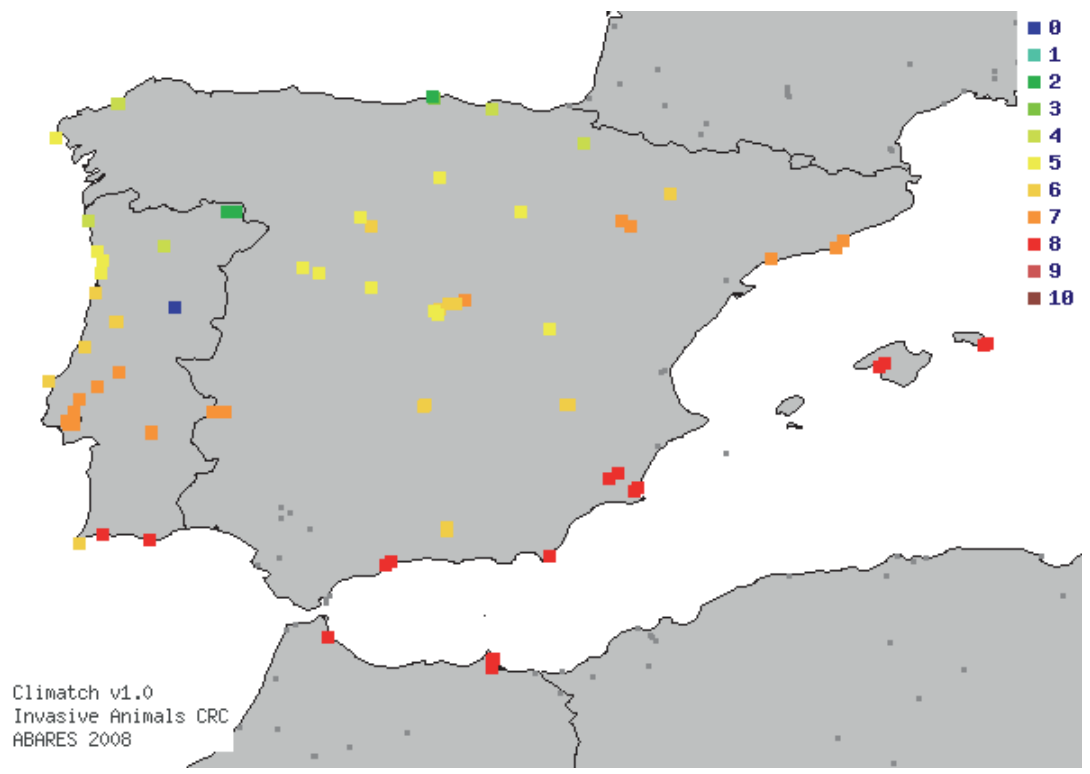

Figure 2. Graphical results of similarity climate analyses conducted for the Iberian Peninsula through 'Climatch'. Analyses were produced using all default variables and 'closest Euclidean match' as a distance measure for 14 source localities with climate stations in the surroundings of the clearly established populations of C. esculenta and 76 target localities (territory covered ca. $472.510 \mathrm{~km}^{2}$ ). The higher the match class, the closer the match of climates between source and target sites (0, minimum matching, 10 , maximum matching). Resultados gráficos de los análisis de semejanza climática realizados para la península ibérica usando 'Climatch'. Los análisis se realizaron usando todas las variables por defecto y el 'Ajuste Euclídeo más próximo' como medida de distancia para 14 localidades fuente con estaciones climáticas en las cercanías de poblaciones establecidas de C. esculenta, y 76 localidades objetivo (cobertura territorial aproximada $472.510 \mathrm{~km}^{2}$ ). El nivel de coincidencia climática entre localidades fuente y objetivo aumenta con la clase de corte (mínima coincidencia en 0 y máxima coincidencia en 10).

Table 2. Climate types of invaded areas worldwide, with type of climate according to Köppen-Geiger's system, updated by Kottek et al. (2006). See text for an explanation of climate classes and abbreviations used. *Records from Portuguese continental localities must be considered at present as ephemerophytes escaped from cultivated lands. Tipos climáticos de áreas invadidas en diversas partes del mundo, según la clasificación climática de Köppen-Geiger, actualizada por Kottek et al. (2006). Véase el texto para una explicación sobre las clases climáticas y las abreviaturas empleadas. * Los registros de las localidades portuguesas deben considerarse, por ahora, como escapes procedentes de cultivos próximos.

\begin{tabular}{llll}
\hline Country & Region & Types of climates & Reference \\
\hline Australia & North & Aw, BSh & NCRIS (2015) \\
& East & Cfa, Cfb & NCRIS (2015) \\
& South-east & Cfb & NCRIS (2015) \\
& South-west (Perth area) & Csa & NCRIS (2015) \\
New Zealand & Northern Island & Cfb & NCRIS (2015) \\
USA & Texas (San Antonio, Onalaska, Houston) & Cfa, Cfb & Moran \& Yang (2012) \\
& Florida (almost all counties) & Cfa, Aw & EDDMapS (2015) \\
Portugal & & & \\
& & & *Sociedad Portuguesa de Botânica \\
& South and Central mainland Portugal* ${ }^{*}$, & Csa, Csb, Cfa, Cfb & (2006) -mainland-; \\
& Madeira, Azores & & Silva et al. (2008) -Atlantic Islands- \\
Spain & & & \\
& Canary Islands & Csb, Bsh & Kunkel (1975) \\
& South coastal areas & Csa & This work \\
& Northeast (Ebro river, coastal area) & Csa & Balada (1993) \\
& Guadalquivir River Basin & Csa & García-de-Lomas et al. (2012) \\
& East (coastal provinces) & BSk & Ferrer-Gallego et al. (2015)
\end{tabular}




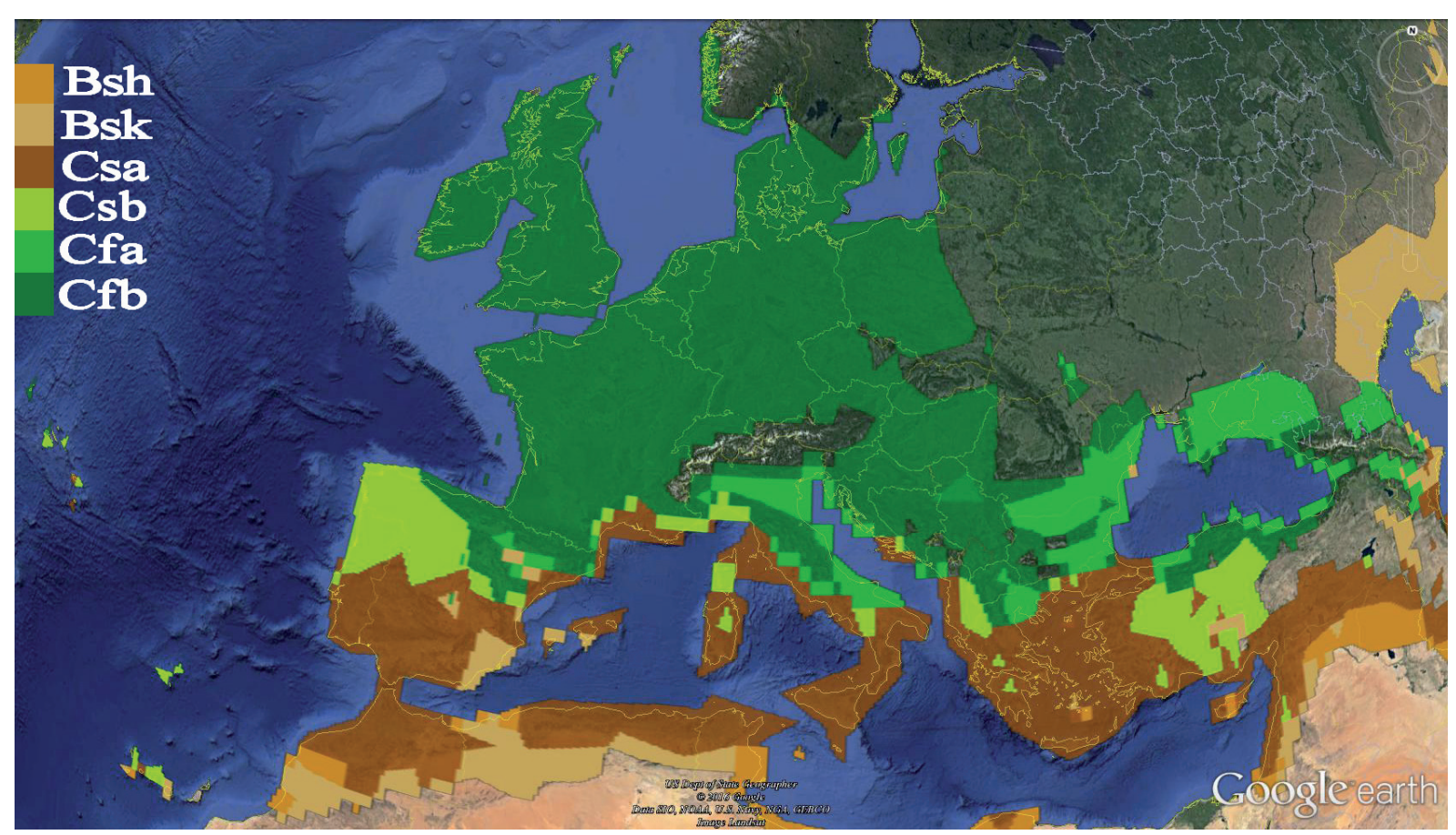

Figure 3. Europe and neighbouring territories with Köppen-Geiger type-climates compatible with C. esculenta requirements. The map has been adapted from that provided by Wilkerson \& Wilkerson (2010), which is based on the original map published by Kottek et al. (2006). Legend letters indicate climate types and sub-types according to Kottek et al. (2006). See text for a description. Regiones europeas (y países del entorno) con tipos climáticos de Köppen-Geiger compatibles con los requerimientos mostrados por C. esculenta. El mapa ha sido adaptado del provisto por Wilkerson \& Wilkerson (2010), que está basado en el publicado por Kottek et al. (2016). Las letras de la leyenda indican los tipos y subtipos climáticos de acuerdo con Kottek et al. (2006). Véase el texto para una descripción.

spectively), a warm and fully humid temperate climate (with hot or warm summer, 'Cfa' and 'Cfb', respectively) and a steppe climate (hot or cold arid, 'BSh' and 'BSk' subtypes, respectively). It is important to highlight that 'Csa', ' $\mathrm{Csb}$ ' and ' $\mathrm{Cfb}$ ' are the subtypes most represented in Europe, both in inland and coastal Europe (Kottek et al., 2006).

\section{Risk analysis and final considerations}

The results of the analysis conducted with 'Climatch' (Fig. 2) demonstrated that a large part of the Iberian Peninsula shares climatic conditions with those present in the already invaded regions. Thus, the Iberian Peninsula represents climate conditions suitable for the establishment of C.esculenta.

The comparison of the Köppen-Geiger climate types present in Europe to those regions worldwide in which $C$. esculenta behaves as a clear invader allows us to conclude that the vast majority of European countries are under climatic conditions that are suitable for the species: Bsh, Bsk, Csa, Csb, Cfa, and Cfb (Kottek et al., 2006). Figure 3 , which is based on the map prepared by Wilkerson \& Wilkerson (2010), shows the distribution and extent of each of these six climate types in Europe. Therefore, it can be concluded that the majority of European countries show climate features compatible with the species' requirements.

According to Rubel \& Kottek (2010), as a result of climate change, the areas characterised by the 'Csa' climate type are predicted to decline and to be replaced by the 'Bsk' type to an important extent in Spain and in some other areas in Europe by 2070-2100. The 'Csa' type climate is also predicted to cover a large part of north-western France that is now covered by 
the 'Cfb' climate type. These authors also found that, assuming an A1FI emission scenario for the period 2076-2100, projections will result in an increased coverage of $31.82 \%$ of ' $\mathrm{B}$ ' climates $(+2.68 \%)$ and $15.20 \%$ of ' $C$ ' climates $(+0.53 \%)$ of the global land area. It must be highlighted that $1 \%$ corresponds to an area of $1.43 \cdot 10^{6} \mathrm{~km}^{2}$.

In the risk analyses conducted, $C$. esculenta was classified as a species showing high risk for wetlands and riversides, regardless of the procedure employed and the geographical scale considered. Using the assessment system proposed by García-de-Lomas et al. (2014), the total score obtained for the species was 73.2 points out of 100 . The procedure presented by Pheloung (1995) and Gordon et al. (2010) yielded a similar result, i.e., that the use of this species should be prohibited, either when applied to the Iberian Peninsula or to continental Europe, with a total score of 9 points out of 29. Both the biological features shown by $C$. esculenta and its potential impact on the ecosystems invaded (e.g., ability to form monospecific dense stands) were responsible for the high risk of invasion. In agreement with Regulation (EU) no. 1143/2014 of the European Parliament and of the Council of 22 October 2014 on the prevention and management of the introduction and spread of invasive alien species, a synthesis of the relevant information for risk analysis is provided in Supplementary Information (Tables S1 and S2, available at www. limnetica.com).

Urbanisation of the surroundings of natural and semi-natural areas has been increasing in the Iberian Peninsula since 1960 (Gormsen \& Klein, 1986). Given the variety of climate types that are adequate for the species, it seems that an increase in the use of $C$. esculenta may represent an increased risk of invasion of the rivers and wetlands of the Iberian Peninsula. Invasion by this species would be a threat added to others such as pollution, destruction of native plant communities and flow reduction. It must be taken into account that the influence of general climate conditions at broad scales may be locally moderated in rivers and wetlands, a fact that could increase the effective potential area for this species. It also seems reasonable to extrapolate these results, at least to other European countries.

Consequently, it seems reasonable to legally regulate the use of this species in Europe. Spain and Portugal have specific legislation on invasive taxa. Therefore, it is proposed to include C.esculenta within the list of invasive alien species banned for use in the Iberian Peninsula. In areas where the species is an ancient crop, such as in the Canary Islands and Azores, with important areas of cultivated lands -called 'ñameras', banning is not a feasible nor realistic option, and hence preventive measures focused on controlling escaped individuals could be promoted.

Spanish and Portuguese public administrations are also recommended to remove all the stands cited in literature to prevent a greater degree of invasion. The efficacy of different control methods (manual removal, application of herbicides (glyphosate), mechanical cutting, a combination of mechanical cutting followed by application of glyphosate to cut petioles and shadowing) has been tested (Atkins \& Williamson, 2008; Ferrer-Gallego et al., 2015). The effectiveness of manual removal is moderate (Atkins \& Williamson, 2008; Ferrer-Gallego et al., 2015). Moreover, physical contact may cause dermatitis because this species contains calcium oxalate (Franceschi \& Nakata, 2005; Oscarsson \& Savage, 2007). In addition, manual removal may result in the multiplication and spread of the species from stolons and corms (Ferrer-Gallego et al., 2015). The use of herbicides in aquatic environments is not generally allowed and may be harmful to non-target aquatic fauna and flora. A promising alternative method is the overshadowing of plant stands by anti-grass double-layer opaque shade cloths (Ferrer-Gallego et al., 2015). This method avoids handling the specimens directly, and by depriving them of light, the plants end up withering and rotting. However, this method is suggested only on banks with heavily invaded monospecific stands and in areas with aggregated and discontinuous distributions of $C$. esculenta. However, when banks are colonised by other species (such as trees or shrubs), the use of this technique might not be 
advised because of potential damage to native communities.

\section{ACKNOWLEDGEMENTS}

Thanks are due to Tobias Schwarz for advice on the use of the climate-data projections contained in www.climate-data.org and to Belinda Mitterdorfer (Plant Biosecurity, Australian Government Department of Agriculture and Water Resources) for sharing information on the Australian Weed Risk Assessment protocol. Finally, Paulo Alves (Centro de Investigação em Biodiversidade e Recursos Genéticos, Universidade do Porto) is thanked for providing data about the Portuguese records. Our gratitude also goes to Alfonso Barragán for alerting us regarding a new population in Sevilla. Special thanks go to two anonymous referees and the associate editor, whose constructive comments considerably improved an earlier version of the manuscript, especially in the section related to climate analyses. We are grateful to the MGC staff for helping us with vouchers handling.

\section{REFERENCES}

ALMEIDA, J. \& H. FREITAS. 2012. Exotic flora of continental Portugal $-\mathrm{a}$ new assessment. Bocconea, 24: 231-237.

ATKINS, E.O. \& P.S. WILLIAMSON. 2008. Comparison of four techniques to control elephant ear. Journal of Aquatic Plant Management, 46: 158-162.

BALADA, R. 1993. Notes florístiques. Butlletí del Parc Natural Delta de l'Ebre, 8: 42.

BOISSIER, E. 1839. Voyage botanique dans le midi de l'Espagne pendant l'année1837. Vol. II. Gide et Cie., Libraires-éditeurs. Paris, France.

BROWN, K. \& K. BROOKS. 2003. Managing Colocasia esculenta invading the fringing vegetation of a fresh water stream north of Perth. Ecological Management and Restoration, 4: 76-77.

CASIMIRO-SORIGUER, F. \& A.V. PÉREZ-LATORRE. 2008. Aproximación al conocimiento de la flora alóctona de la provincia de Málaga (España): catálogo de metáfitos. Acta Botanica Malacitana, 33: $373-382$.
CROMBIE, J., L. BROWN, J. LIZZIO \& G. HOOD. 2008. Climatch User Manual. Australian Government acting through the Bureau of Rural Sciences.Canberra. [http://data.daff.gov.au:8080/ Climatch/climatch.jsp, accessed 10/06/2016].

CUFODONTIS, G. 1953-1972. Enumeratio Plantarum Aethiopiae, Spermatophyta. Bulletin du Jardin Botanique National de Belgique: 1499. Bruxelles.

CURCÓ, A. 2007. Flora vascular del delta de l'Ebre. Col-lecció Tècnica, 1. Generalitat de Catalunya, Departament de MediAmbient i Habitatge, Parc Natural del Delta de l'Ebre. $1^{\mathrm{a}}$ edició. Deltebre. Spain.

EDDMAPS (Early Detection \& Distribution Mapping System). 2015. The University of Georgia. Center for Invasive Species and Ecosystem Health. [http://www.eddmaps.org/, accessed 20/07/ 2015]

ELMORE, K.L. \& M.B. RICHMAN. 2001. Euclidean distance as a similarity metric for principal component analysis. Monthly Weather Review, 129: 540549.

EPPO (European and Mediterranean Plant Protection Organisation). 2014. Plant Quarantine Data Retrieval System database. Paris, France [http://www. eppo.int/DATABASES/pqr/pqr.htm, accessed 20/ 11/2015]

FERRER-GALLEGO, P.P, V. DELTORO, A. SEBASTIAN, C. PEÑA, P. PÉREZ \& E. LAGUNA. 2015. Sobre la presencia y control de Colocasia esculenta (L.) Schott (Araceae, Colocasieae) en la Comunidad Valenciana. Bouteloua, 22: 215-221.

FLEPPC (Florida Exotic Pest Plant Database). 2000. Colocasia esculenta. [http://www.eddmaps.org/flo rida/species/subject.cfm?sub=5369, accessed 7/07/ 2015]

FRANCESCHI, V.R. \& P.A. NAKATA. 2005. Calcium oxalate in plants: formation and function. Annual Review of Plant Biology, 56: 41-71.

FUJIMOTO, T. 2009. Taro (Colocasia esculenta [L.] Schott) cultivation in vertical wet-dry environments: farmers' techniques and cultivar diversity in Southwestern Ethiopia. Economic Botany, 63: 152-166.

GARCÍA-CAMACHO, R. \& A. QUINTANAR. 2003. Estudio preliminar de las plantas vasculares alóctonas de los Parques Nacionales españoles. Real Sociedad Española de Historia Natural, Madrid, Spain.

GARCÍA-DE-LOMAS, J., E.D. DANA \& G. CEBALLOS. 2012. First report of an invading population 
of Colocasia esculenta (L.) Schott in the Iberian Peninsula. BioInvasions Records, 1: 139-143.

GARCÍA-DE-LOMAS, J., E.D. DANA, G. CEBALLOS \& F. ORTEGA. 2014. Análisis del riesgo de invasión de vegetales exóticos. Manual práctico. Consejería de Medio Ambiente y Ordenación del Territorio. Junta de Andalucía. Sevilla, Spain.

GARCÍA-SÁNCHEZ, E., J.E. HERNÁNDEZ-BERMEJO, J.M. CARABAZA, A. JIMÉNEZ-RAMÍREZ \& E. MARTÍN-CONSUEGRA. 2008. Plantas hortenses en al-Andalus: Monocotiledóneas. In: Ciencias de la Naturaleza en Al-Andalus. Textos y estudios, VIII. GARCÍA-SÁNCHEZ E. \& C. ÁLVAREZ DE MORALES (eds.): 123-200. CSIC, EEA, Granada, Spain.

GARCÍA-SÁNCHEZ, E. 2013. Los sistemas de injerto en la agronomía andalusí. Manuscrits. Revista d'Història Moderna, 31: 41-63.

GORDON, D.R., B. MITTERDORFER, P.C. PHELOUNG, S. ANSARI, C. BUDDENHAGEN, C. CHIMERA, C.C. DAEHLER, W. DAWSON, J.S. DENSLOW, A.M. LAROSA, T. NISHIDA, D.A. ONDERDONK, F.D. PANETTA, P. PYSEK, R.P. RANDALL, D.M. RICHARDSON, N.J. TSHIDADA, J.G. VIRTUE \& P.A. WILLIAMS. 2010. Guidance for addressing the Australian Weed Risk Assessment questions. Plant Protection Quarterly, 25: 56-74.

GORMSEN, E. \& R. KLEIN. 1986. Recent trends of urban development and town planning in Spain. GeoJournal, 13: 47-57.

HENDERSON, L. 2007. Invasive, naturalized and casual alien plants in southern Africa: a summary based on the Southern African Plant Invaders Atlas (SAPIA). Bothalia, 37: 215-248.

KORNAŚ, J. 1990. Plants invasions in Central Europe: historical and ecological aspects. In: Biological Invasions in Europe and the Mediterranean Basin. DI CASTRI, F., A. J. HANSEN \& M. DEBUSSCHE (eds.): 105-133. Kluwer Academic Publishers, Amsterdam. The Netherlands.

KOTTEK, M., J. GRIESER, C.H. BECK, B. RUDOLF \& F. RUBEL. 2006. World map of the Köppen-Geiger climate classification updated. Meteorologische Zeitschrift, 15: 259-265.

KUNKEL, G. 1975. Novedades y taxones críticos en la flora de La Gomera. Cuadernos de Botánica Canaria, 25: 17-49.

LOY, T.H., M. SPRIGGS \& S. WICKLER. 1992. Direct evidence for human use of plants 28,000 years ago: starch residues on stone artefacts from the northern Solomon Islands. Antiquity, 66: 898-912.

MACE, E.S. \& I.D. GODWIN. 2002. Development and characterization of polymorphic microsatellite markers in taro (Colocasia esculenta). Genome, 45: 823-832.

MORAN, P.J. \& C. YANG. 2012. Distribution of wild taro (Colocasia esculenta) in subtropical Texas, growth of young colonies, and tolerance to simulated herbivory. Subtropical Plant Science, 64: 1828.

MOREIRA, J. M. 2011. Urbanismo expansivo: de la utopía a la realidad. Reflexiones desde la información ambiental. XXII Congreso de la Asociación de Geógrafos Españoles. Alicante. [http://www. cma.junta-andalucia.es/medioambiente/portal_web/ rediam/productos/Publicaciones/congresos/urbanismo _expansivo_andalucia.pdf, accessed 27/09/2015].

NCRIS -National Research Infrastructure of Australia-. 2015. The Atlas of Living Australia. [http://bie. ala.org.au/species/urn:lsid:biodiversity.org.au:apni. taxon:314055, accessed 20/7/2015].

ONWUEME, I. 1999. Taro cultivation in Asia and the Pacific. Food and Agriculture Organization of the United Nations. Regional Office for Asia and the Pacific. Bangkok, Thailand.

OSCARSSON, K.V. \& G.P. SAVAGE. 2007. Composition and availability of soluble and insoluble oxalates in raw and cooked taro (Colocasia esculenta var. Schott) leaves. Food Chemistry, 101: 559-562.

PARDALES, J.R., Jr., Y. KONO, A. YAMAUCHI \& M. IIJIMA. 1992. Seminal root growth in sorghum (Sorghum bicolor) under allelopathic influences from residues of taro (Colocasiaesculenta). Annals of Botany, 69: 493-496.

PÉREZ-LARA, J.M. 1886. Florula gaditana. Pars prima. Anales Sociedad Española de Historia $\mathrm{Na}$ tural, 15: 349-475.

PHELOUNG, P.C. 1995. Determining the weed potential of new plant introductions to Australia. Perth, Western Australia: Agriculture Protection Board Report, West Australian Department of Agriculture.

PLUCKNETT, D.L. 1976. Edible aroids: Alocasia, Colocasia, Cyrtosperma, Xanthosoma. In: Evolution of crop plants. SIMMONDS, N. W. (ed.): 10-12. Longman Press, London.

ROYO, F. 2006. Flora $i$ vegetació de les planes i serres litorals compreses entre el riu Ebro i la serra d'Irta. Universidad de Barcelona. 
RUBEL, F. \& M. KOTTEK. 2010. Observed and projected climate shifts 1901-2100 depicted by world maps of the Köppen-Geiger climate classification. Meteorologische Zeitschrif, 19: 135-141.

SANZ-ELORZA, M., E.D. DANA \& E. SOBRINO. 2004. Atlas de las plantas alóctonas invasoras en España. Dirección General para la Biodiversidad. Madrid Spain.

SEQUEIRA, M., D. ESPÍRITO-SANTO, C. AGUIAR, J. CAPELO \& J.J. HONRADO. 2011. Checklist da Flora de Portugal Continental, Açores e Madeira. [http://bibdigital.rjb.csic.es/PDF/Sequeira_y_al_ Checklist_Flora_Portugal_2011.pdf, accessed 30/ 05/2016].

SILVA, L., R. CORVELO, M. MOURA, R. JARDIM \& J.A. REYES BETANCORT. 2008. Colocasia esculenta (L.) Schott. In: Invasive Terrestrial Flora \& Fauna of Macaronesia. TOP 100 in Azores, Madeira and Canaries. SILVA L., E. OJEDALAND \& J.L. RODRÍGUEZ-LUENGO (eds.). Agência Regional da Energia e Ambiente da Região Autónoma dos Açores, Ponta Delgada.

SOCIEDADE PORTUGUESA DE BOTÂNICA. 2016.

Flora-On: occurrence data of the flora of mainland Portugal. [http://www.gbif.org/occurrence/124883 4511; http://www.gbif.org/occurrence/1248834507; http://www.gbif.org/occurrence/1248834533, accessed 30/05/2016].
TYE, A. 2001. Invasive plant problems and requirements for weed risk assessment in the Galapagos Islands. In: Weed Risk Assessment. GROVES, R.H., F.F. PANETTA \& J.G. VIRTUE (eds.): 153175. CSIRO, Collingwood, Australia.

VISSER, J.M., C.E. SASSER, R.H. CHABRECK \& R.G. LINSCOMBE. 1999. Long-term vegetation change in Louisiana tidal marshes, 1968-1992. Wetlands, 19: 168-175.

WESTER, L. 1992. Origin and distribution of adventive alien flowering plants in Hawai'i. In: Alien plant invasions in native ecosystems of Hawai'i: management and research. STONE, C.P., C.W. SMITH \& J.T. TUNISON (eds.): 99-154. UH Coop. National Park. Resource Study Unit, UH Press, Honolulu.

WILKERSON, M.S. \& M.B. WILKERSON. 2010. Köppen-Geiger climate classification KMZ file for use in Google Earth, DePauw University, Greencastle, IN, USA [http://koeppen-geiger.vu-wien. ac.at/data/Koeppen-Geiger-GE.kmz.zip, accessed 10/06/2016].

WIRTH, F.F., K.J. DAVIS \& S.B. WILSON. 2004. Florida Nursery Sales and Economic Impacts of 14 Potentially Invasive Landscape Plant Species. Journal of Environmental Horticulture, 22: 12-16. 